Daniel Weidner · Sigrid Weigel (Hrsg.)

Benjamin-Studien 2 

Daniel Weidner · Sigrid Weigel (Hrsg.)

Benjamin-Studien 2

Wilhelm Fink 
Bibliografische Information der Deutschen Nationalbibliothek

Die Deutsche Nationalbibliothek verzeichnet diese Publikation in der Deutschen Nationalbibliografie; detaillierte bibliografische Daten sind im Internet über http://dnb.d-nb.de abrufbar.

Alle Rechte, auch die des auszugsweisen Nachdrucks, der fotomechanischen Wiedergabe und der Übersetzung, vorbehalten. Dies betrifft auch die Vervielfältigung und Übertragung einzelner Textabschnitte, Zeichnungen oder Bilder durch alle Verfahren wie Speicherung und Übertragung auf Papier, Transparente, Filme, Bänder, Platten und andere Medien, soweit es nicht $\$ \$ 53$ und 54 UrhG ausdrücklich gestatten.

(C) 2011 Wilhelm Fink Verlag, München

(Wilhelm Fink GmbH \& Co. Verlags-KG, Jühenplatz 1, D-33098 Paderborn)

Internet: www.fink.de

Die Drucklegung dieses Werkes wurde unterstützt mit den Mitteln des Bundesministeriums für Bildung und Forschung unter dem Förderkennzeichen 1UG0712.

Lektorat: Bettina Moll, Berlin

Satz: Tilo Lothar Rölleke, Berlin

Einbandgestaltung: Evelyn Ziegler, München

Printed in Germany

Herstellung: Ferdinand Schöningh GmbH \& Co. KG, Paderborn

ISBN 978-3-7705-5071-5 
José M. GonZÁlez García

\section{Walter Benjamin: The Angel of Victory and the Angel of History ${ }^{1}$}

Walter Benjamin's $9^{\text {th }}$ thesis on the concept of history is his most-quoted and -commented text. As it is well known, his idea of the "Angel of History« appears as a commentary on Paul Klee's famous watercolor titled Angelus Novus. I think it is necessary to open another way of interpretation through the connection of Benjamin's Angel of History with the political iconography of Berlin, the city where he was born and lived for many years and about which he wrote in his memories of childhood, his Berlin chronicles and radio programs. I shall begin the historical narrative of Berlin's political iconography with a figure to which Benjamin paid little attention: the Goddess Fortune.

Berlin's public sphere was symbolically dominated by the Goddess Fortune during the Baroque period and part of the $18^{\text {th }}$ Century. In the $19^{\text {th }}$ Century, the preeminence is given to another potent image which permeates all the political life: The Angel of History. The transition between the two images implies a shift from a conception of politics in which outside circumstances impose changes to a perspective of complete assurance in their own forces which, linked to the progress of the economy, of industrialization as well as of the bureaucratic organization of the army and society, will set in motion the forward march of history in a permanent victory over other peoples and, especially, over France. A transformation, then, of instability and of sudden and uncontrollable change at the hands of the Goddess of Fortune to a situation of permanent progress in which the future assures the supremacy of German society and the continued march toward the future, represented by the Goddess Nike or the Goddess of Victory. Symbolically, this involves a change of goddesses in the political realm which expresses two completely different perspectives on German self-conception: the passage, from a subjection to events which are imposed upon free will, to a new situation ruled by the idea of control of the future and confidence in progress and in their own force. On the other hand, the Goddess of Victory is transformed into an angel from a Christian mold,

1 A work undertaken within the Investigation Project FFI2008-05054-C02-01/FISO, financed by the Spanish Ministry of Science and Innovation. It was written in: Zentrum für Literaturund Kulturforschung (ZfL), thanks to a DFG's grant. I am also grateful to the members of my research project and to Sigrid Weigel and all the members of ZfL. 
because the Goddess Nike remains alien in the popular mind. This transformation takes place in a natural way, given that the symbols of the figures are the same: the wings of Victory are also the wings of the angel, and the objects they carry in their hands are identical in both cases: the laurel wreath and the palm of victory.

In Berlin Childhood around 1900, Benjamin analyzes the "Victory Column" and how he himself was educated in the values of German nationalism, for example through the Sedan Day celebration commemorating the military victory over France in 1871. Despite being educated in the idea of history from the point of view of the winners, Benjamin posits the need for writing history from the point of view of the defeated. The image of this change is precisely the Angel of History. Benjamin himself was defeated in his attempt to escape the Nazis through the Pyrenees and was defined after his suicide at the Spanish border as an "Angel without Fortune." Thus an iconographic cycle that begins with the Goddess Fortune and continues with the change into the Goddess of Victory and her transformation into the Angel of Victory, comes to a close. The cycle continues with Benjamin's Angel of History and closes with Benjamin himself as an »Angel without Fortune. $\aleph^{2}$ Thus, it moves from Fortune to Angel and from there to the Angel without Fortune.

\section{From the Goddess Fortune to the Goddess Nike in Berlin}

The best example of the Goddess Fortune's political dominion in Berlin of the $17^{\text {th }}$ Century and part of the $18^{\text {th }}$ is the Baroque palace of Charlottenburg. Ordered to be constructed at the end of the $17^{\text {th }}$ Century and inaugurated in 1699 as the Lietzenburg Palace for Sophie Charlotte, the second wife of the Great Elector of Brandenburg, Frederick III, who in 1701 would ascend to the Prussian throne with the name Frederick I, the palace was named Charlottenburg in honor of the queen and also gives its name to one of the best-known neighborhoods of West Berlin. Sophie Charlotte's premature death prevented her from enjoying the magnificent installations and vast gardens for very long. Those were the gardens where the famous "philosophical walks" took place during which, as it is told, Gottfried Wilhelm Leibniz had explained to Sophie Charlotte the basic principles of his Theodicy, showing the queen how the omnipotence of God could be reconciled with the problem of the existence of evil in the world, and answering her innumerable questions. In the expansion from 1710 to 1712 , the palace received the current cupola which fully dominates its

2 Walter Benjamin: Glückloser Engel. Dichtungen zu Walter Benjamin, Frankfurt a. M. et al. (Suhrkamp/Insel) 1992. 
profile. Above the cupola's crown, and transformed into a weather vane, we are shown the power of the Goddess of Fortune over human affairs and, especially, over politics. It does not cease to be curious that Franz Hessel, friend and collaborator of Walter Benjamin, did not see in this figure a representation of the Goddess of Fortune, but rather of the God of Dance, dancing at the top of the cupola of the architect Eosander. ${ }^{3}$

On the other hand, it is possible to argue that we should not give great symbolic importance to the placement of the Goddess of Fortune in a summer or pleasure palace as is the case of Charlottenburg. It is always possible to find some whimsical element in a Lustschloss and a playful vision of the Goddess of Fortune ruling over the political power of the kings can be permitted without taking it too seriously. But this interpretation would not do justice to the situation, for the same statue of the Goddess of Fortune was originally designed by Schlüter for the Münzturm (Tower of the Mint) of the old Schloss or the Hohenzollern Palace, in the centre of Berlin, seat of the representation and the exercise of power of the monarchs. The transfer of the Goddess of Fortune to the summer palace of Charlottenburg is due to the fact that said tower of the central palace could not bear the weight of the statue and threatened to crumble, a fact which doesn't cease to have its symbolic value: the very building of power cracked or even collapsed under the power of the Goddess of Fortune. ${ }^{4}$ The statue was destroyed in one of the bombings of the Second World War, in November of 1943, symbolically signalling the disgrace which hovered over the city. The image which we see now, worthy successor of the earlier piece, is the work of Richard Scheibe.

Ill. 1: Charlottenburg Palace, Berlin.

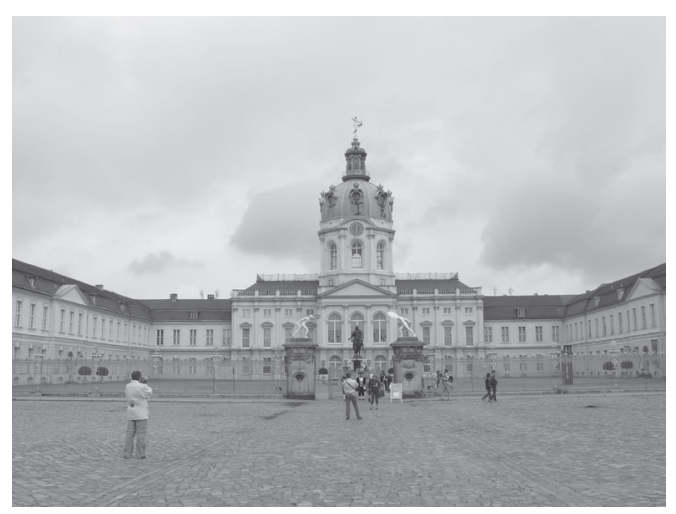

3 Cf. Franz Hessel: Spazieren in Berlin. Beobachtungen im Jahr 1929, Berlin (Buchverlag der Morgen) 1979, p. 119.

4 Cf. Margarethe Kühn: „Antikenverständnis am Berliner Hof von Kurfürst Joachim II. bis zu König Friedrich dem Großen«, in: Willmuth Arenhövel (ed.): Berlin und die Antike. Katalog, Berlin (Deutsches Archäologisches Institut) 1979, p. 30. 
The Goddess of Fortune, as the crown of this Baroque palace which is the representation of power, means the following:

a) Fortune (and not Reason or Wisdom) rules over the spatial complex of the Palace and power is in her hands as the Goddess of Luck. No matter how much we try to rationalize power, its secrets always escape us and we depend on the will of a goddess who spins the wheel of events, provoking downfall, death and disgrace.

b) The Goddess Fortuna symbolizes precisely that constant change of events in the areas of political or military power, and also in the private sphere of individual life or the lives of the monarchs. The premature death of Queen Sophie Charlotte, who the palace is dedicated to, remains significant. Life and death are also in the hands of the Goddess Fortuna.

c) The Goddess of Fortune constantly dances above the sphere of the world. This sphere means two things: on the one hand, it is the symbol of the Goddess Fortuna's power above the roundness of the earth and on the other it is the symbol of instability, for to dance upon a sphere is a difficult exercise which will end in an inevitable downfall. In fact, the figure appears with a single foot upon the sphere while it maintains the other upheld in that dance step which inevitably will provoke her fall.

d) The Goddess Fortuna is a weather vane that changes direction with the wind of history.

e) She holds in one hand a ship's sail, because since Medieval times, Fortuna was the name of the sea winds which produced storms and the resulting sinking of the warships or merchant ships. In mythology, Fortuna, like Venus, was a daughter of the Ocean.

The palace was bombed in the Second World War: it suffered severe damage, the Goddess of Fortune was destroyed and the gardens ruined. Slowly reconstructed in stages after 1946, today it once again shows its old splendor. In the 1950s, an equestrian statue of the Prussian King Frederick I (earlier Frederick III, Great Prince Elector of Brandenburg) was erected in its Honour Courtyard, with a representation of the Goddess of Fortune offering herself to the queen depicted on its plinth. And in recent decades, a statue of the King of Prussia Frederick II the Great has been placed in the front gardens in front of what is called the palace's "new wing." The statue, a copy of the work of Johann Gottfried Shadow (17641850), shows the noble Frederick with military symbols, as a jurist and protector of the peace. The statue has been placed before the expanded wing which he had ordered, and in which he spent his summer residences until the Sanssouci Palace in Potsdam was completed. 


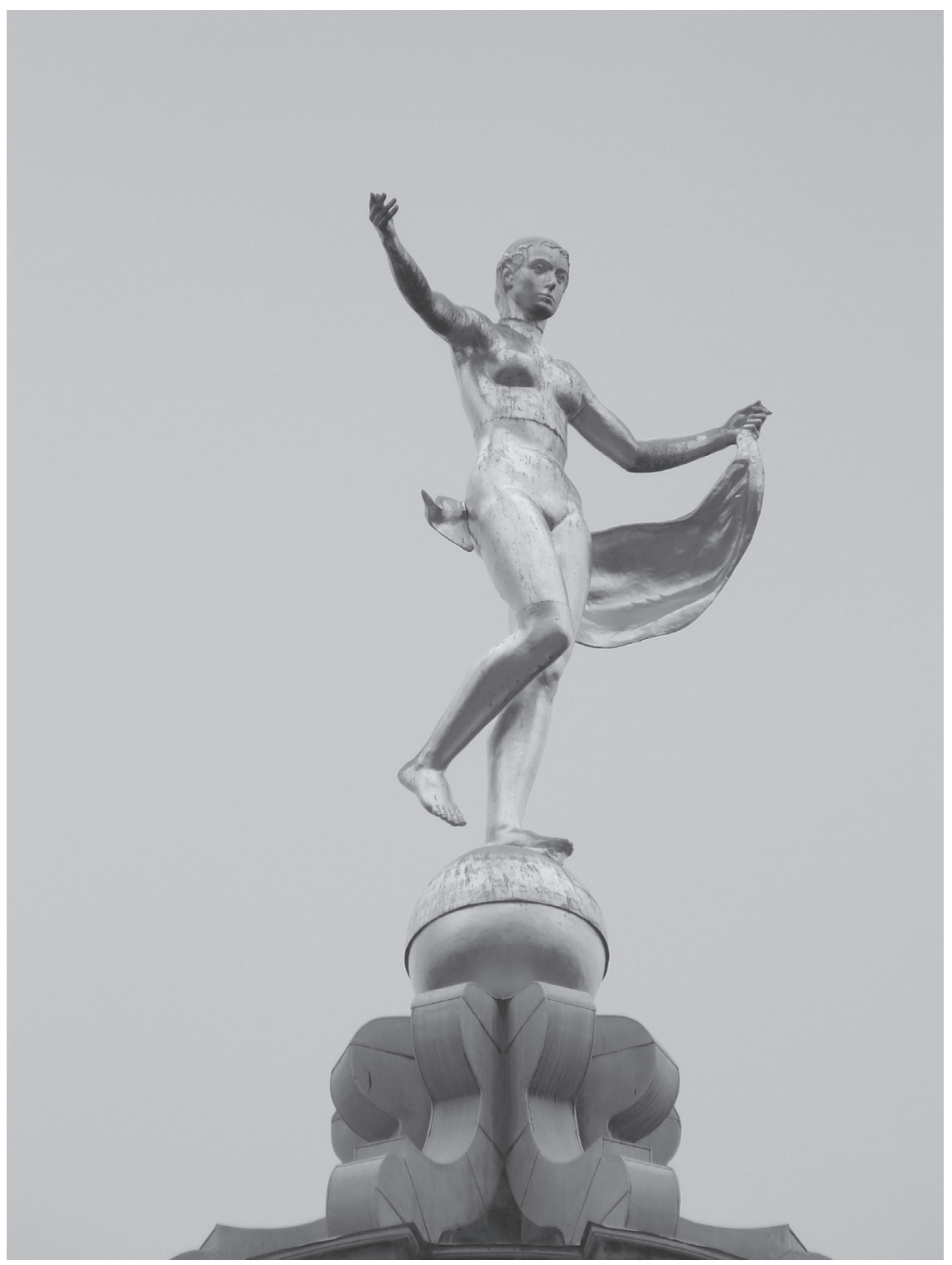

Ill. 2: The Triumph of the Goddess Fortuna as a weather vane on top of the cupola of the Charlottenburg Palace. 


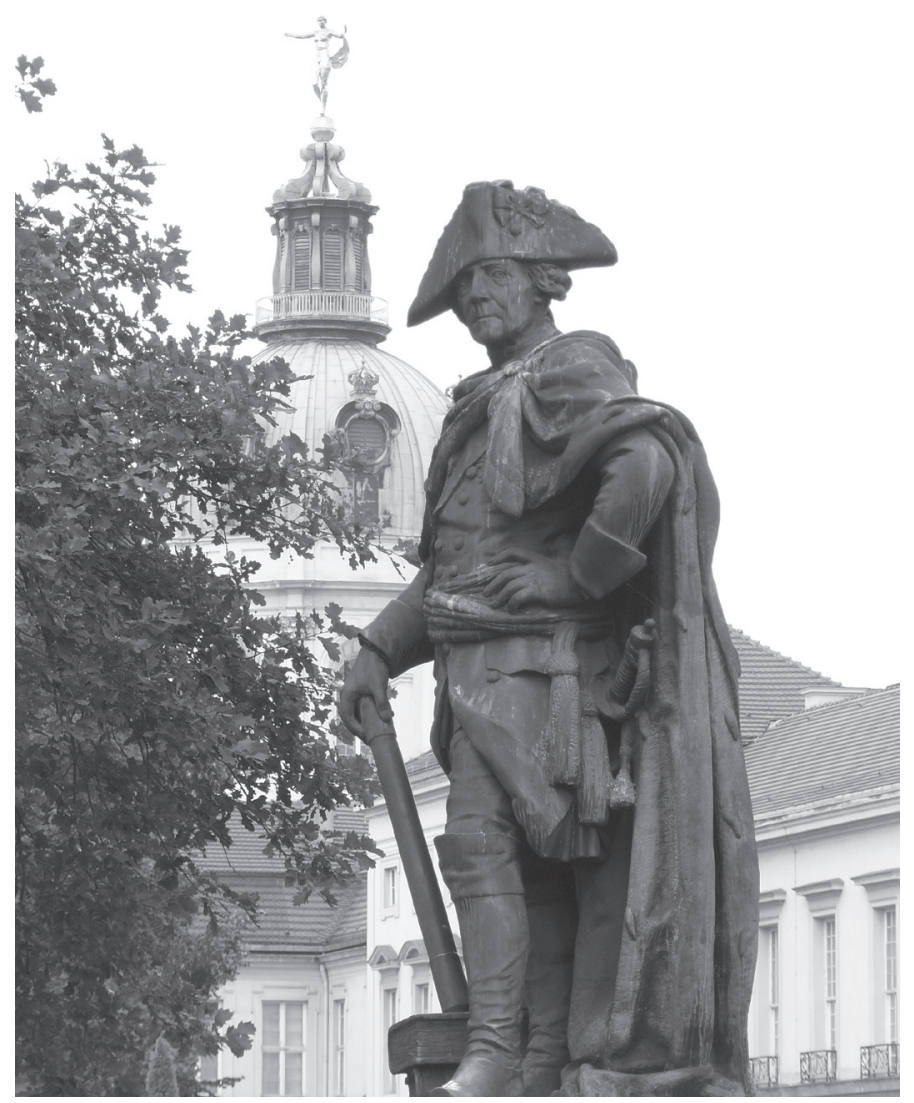

Ill. 3: Frederick II under the gaze of the Goddess Fortuna.

We can consider this image of Frederick II of Prussia in which he appears subordinate to the power of the Goddess of Fortune, situated above him in a higher plane, as the goddess' vengeance, for when he was a young prince he had written against her, in the enlightened spirit of the century, in his critical comments about Machiavelli's The Prince.

There are two different but related ways in which the Goddess Fortuna finds herself defeated in a progressive fashion over the course of the $18^{\text {th }}$ Century and they are illustrated in basic images in the $19^{\text {th }}$ Century. The first consists of Fortuna's overthrow by the Victory of weaponry, due to the military organization, the state 
bureaucracy and the development of war techniques. Victory no longer depends on good or bad Fortune, but rather on political and military reason and on social organization, on the proper functioning of the bureaucracy and on the correct decisions of the nation's government. And this is symbolically expressed in the proliferation of Goddess Nikes or Angels of Victory in Berlin, and also in other German cities.

But the Goddess Fortuna is also defeated by the development of industry and by the idea of the indefinite progress of the German State. As an example, we can examine a coin from 1835 on which Industry appears with the ancient Wheel of Fortune now converted into the wheel of the train of progress. Another iconographic example is found in the allegories which adorn the Reichstag, the most politically important building of the $19^{\text {th }}$ Century in Berlin, built between 1884 and 1894 in an historicist style in vogue in the era. We no longer find Fortuna among the numerous allegorical sculptures which adorn it, but rather "Industry,«»Electricity,«»Commerce and Navigation,«»Agriculture« or »Livestock, « all emblems of technical and economic progress. We also find the allegories of Law or of the "Art of the Political" which symbolize other forms of social and historic progress. Nothing is left in the hands of volatile Goddess Fortuna any longer and it would be inconceivable in the $19^{\text {th }}$ Century to repeat the Baroque idea of placing the goddess as the crown of a public building. ${ }^{5}$

\section{The political importance of Angels: From the Goddess Nike to the Angel of Victory}

Let us now leave for a moment the exterior of the Charlottenburg Palace where the Goddess Fortuna reigns and let us go to the interior where we find a predominance of angels, especially in the chapel. The Goddess Fortuna's victory in the exterior is compensated by the angels which conquer the interior religious and political space. The entire chapel is an explosion of angels: countless large angel altarpieces with symbols of victory, angels on the roof which support a legend about King Frederick's piety, above which there rests a crown and, above all, the angels which blow abundant trumpets of his fame while at the same time they support the monarchy's crown, which they carry down from the heavens to the earth. They are the angels of Baroque decoration who miraculously remain in the air while they show us the relationship between religious and political power, between the power of God and that of the kings, of the alliance between the Altar and the Throne. Other angels reveal the symbol of the eagle, that symbol

5 Cf. the description of the building of the Reichstag in: Paul Wietzorek: Das historische Berlin. Bilder erzählen, Petersberg (Michael Imhof) 2006, p. 173-179. 
of the Gospel of Saint John and also of the Hohenzollern dynasty. Angels appear as mediators between God and the monarchy of divine origin in that special way of Reformed Protestant "political theology" of the Hohenzollern: therefore, it is angels who carry the crown and bring it down from the heavens to earth as messengers of God. Paraphrasing Carl Schmitt, it would be suitable to say that not only do all the political concepts have a religious origin, but also all the images of power: of course Fortuna has her origin in the Greek or Roman pantheon and the

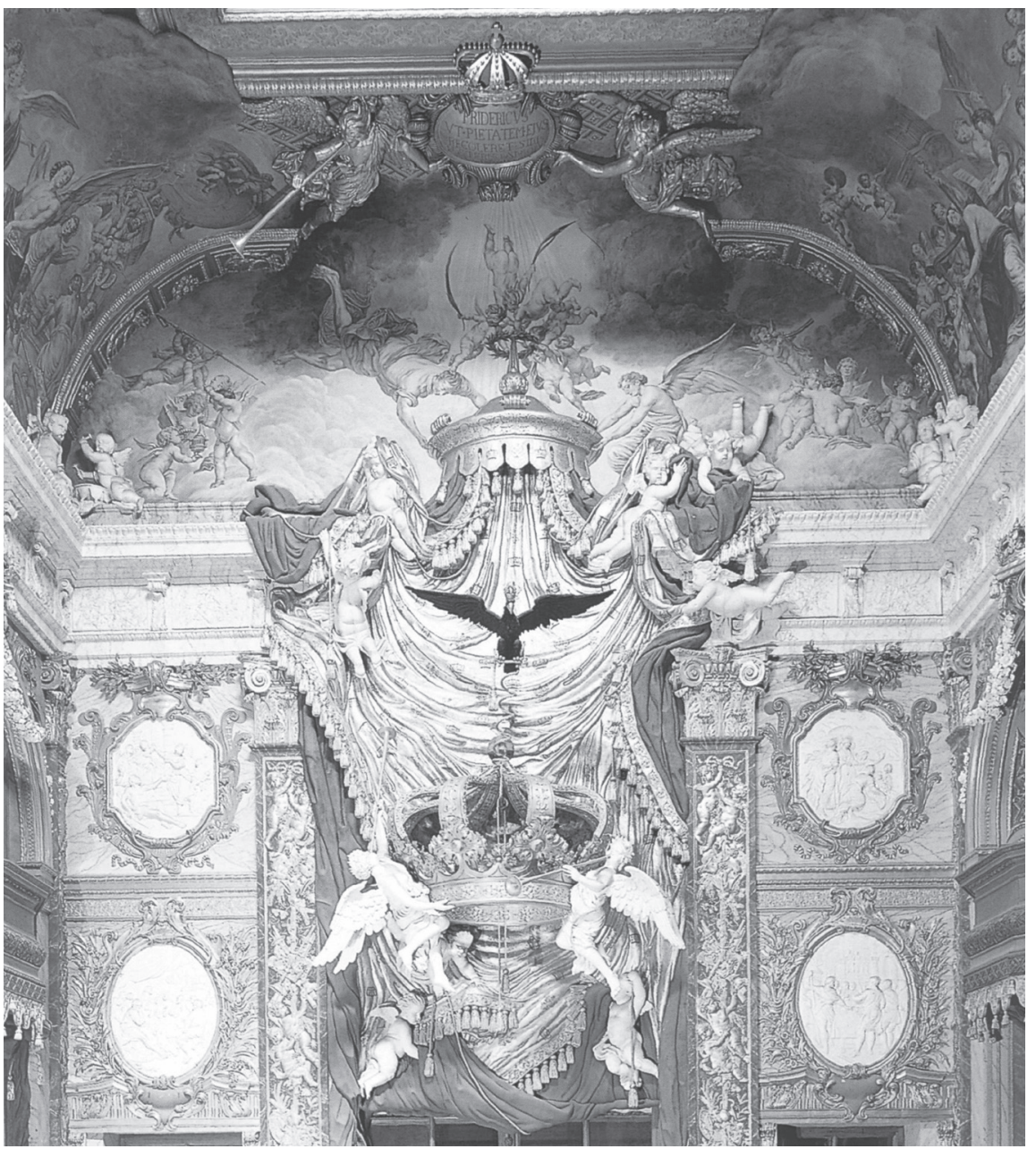

Ill. 4: Angels of the chapel in Charlottenburg Palace. 
angels in the Christian theological traditions, whether these are Catholic or inheritors of the Protestant reform. The angels are also the consolers of the disgraces which afflict mortals and, especially, the kings. Therefore they predominate in the private realm of the palaces, as we can see in the description that Fontane made of the small palace of Paretz in his journeys through Mark Brandenburg. ${ }^{6}$

On the other hand, it is not excessive to note here that Walter Benjamin, in the final pages of his book about the Trauerspiel notes that the Baroque style, after the Counter-Reformation and especially after the Council of Trent, tries to give artistic expression to the Aristotelian idea of the miracle, of that which provokes wonder or awe, by means of the angels which dominate the architecture and above all the interior decoration of the buildings:

The impression of supernatural forces is supposed to be aroused in the powerfully projecting and apparently self-supporting structures precisely in the upper regions, interpreted and accentuated by the perilously soaring angels of the sculptural decoration $[\ldots]$. $^{7}$

Although Benjamin speaks of the Baroque Churches of the Catholic CounterReform, in the case of the chapel of the Charlottenburg palace, we find ourselves with a similar situation in which the angels, moving suspended in the air, make the royal crown descend from the heavens to the mortal realm as a practical illustration of the reformed political theology which also insists on the divine origin of the authority of the monarchs of the Hohenzollern line.

But let us return again to the exterior of the Charlottenburg Palace where in the rear of the building, near to the so called Schinkel pavillion and on both sides of the avenue that runs along the entire north side, separating it from the gardens, we find two Goddesses Nikes, works of Christian Daniel Rauch in commemoration of the victory of the Prussian troops in the Napoleonic wars. These sculptures by Rauch appear after the victory of the Prussian troops, in alliance with other European armies, over Napoleon's forces in the final battle of Waterloo. The Charlottenburg Palace is thus converted into a center of the symbolic change coming about in Prussia from the preeminence and triumph of the Goddess Fortuna until her decline and substitution by the figure of the Greek Goddess Nike.

6 Theodor Fontane: Wanderungen durch die Mark Brandenburg, München (Carl Hanser) 1987, vol. 2, p. 330-337.

7 Walter Benjamin: The Origins of German Tragic Drama, Thetford (NLB) 1977, p. 234. 


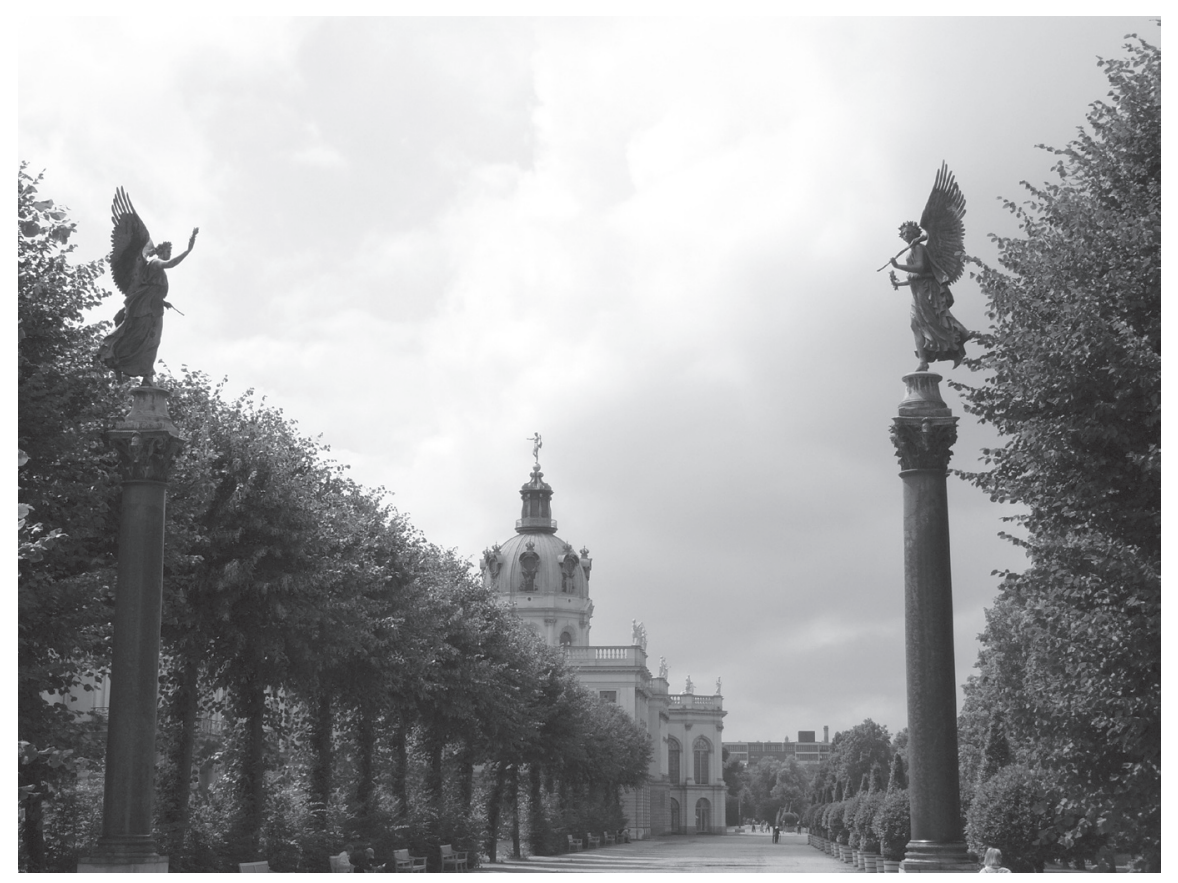

Ill. 5: Goddesses (or Angels) of Victory.

But the metamorphosis of the political symbols doesn't stop there. In addition, for the large majority of the population the Greek Nike becomes a Christian Angel of Victory. The same image can be interpreted in both ways given that their primary symbolic elements are the same: a winged figure that carries in her hands the laurel (or oak) wreath and the palm of victory. In fact, the triumphant statues were understood as the Goddess Nike by the military, the aristocracy and the educated classes who knew the world of the Greek pantheon and wished to convert Berlin into an "Athens of the North." But the figures of the Greek pantheon remained foreign for the popular masses, who tried to translate them into better known and closer figures. In the case of Nike it was easy to reinterpret her as an angel from the Christian tradition. There are many reasons which support the equivalence between the Greek Goddess Nike and the Christian Angel of Victory, but I lack the space to detail them in this article.

Over the course of the $18^{\text {th }}$ Century and especially in the $19^{\text {th }}$, Berlin was considered as the "Athens of the North." Statues of Athena as protecting goddess of the city and instructor of the youth in the techniques of war and of artistic creation 
were common in the city's public spaces. The need to saturate the German spirit with Greek culture was a central theme of the vision which the Germans had of themselves and, for example, Nietzsche, in the work which he wrote in the time of the Franco-Prussian War, established the need to go beyond Schiller, Goethe, and Winckelmann in the attempt to "force open that magic door which leads to the Hellenic magic mountain, " in that urge to make real in Germany the spirit and culture of the Greeks. Nietzsche called for following and surpassing Schiller and Goethe's attempts to not despair totally of the German spirit, penetrating the nucleus of the Hellenic being and establishing an enduring loving alliance between German and Greek culture. ${ }^{8}$

It is worth remembering that Walter Benjamin himself interprets his childhood through a connection with the Greek world, two lost paradises which mutually call to one another. In the book which collects scenes from his childhood, we can read how Greek mythology is embodied in the garden of his childhood (the Tiergarten) and how Berlin's Old West is transformed into the West of Ancient Greece:

Under their tutelage, the Old West district [of Berlin] became the West of antiquity - source of the west winds that aid the mariners who sail their craft, freighted with the apples of the Hesperides, slowly up the Landwehr Canal, to dock by the Hercules Bridge. And once again, as in my childhood, the Hydra and the Nemean Lion had their place in the wilderness that surrounds the Great Stern [Großer Stern]. ${ }^{\text {? }}$

In his memoirs, Benjamin mixes real elements present in Berlin with elements from Greek mythology: statues of the Hydra and of the Lion of Nemea existed in his favorite park, and the Hercules Bridge crossed the canal which demarked Berlin's terrestrial line of defence (Landwehrkanal) in the $18^{\text {th }}$ Century and which today crosses through the centre of the city. The roundabout of the Großer Stern or Great Star also existed and was found in the middle of the most-forested and least-travelled part of the Tiergarten, nowadays a very busy traffic area. None the less, the Apples of the Hesperides and the zephyr which blows the ship are introductions by Benjamin which don't strike a dissonant note in this context, in an era which sought to Hellenize the city. A labor added to Hercules' original ten was precisely to rob the apples from Hera's garden, the golden apples of

8 Cf. in particular ch. 20 of Friedrich Nietzsche: Die Geburt der Tragödie (The Birth of Tragedy), in: id.: Sämtliche Werke, critical student edition in 15 vols., ed. by Giorgio Colli/Mazzino Montinari, München (Deutscher Taschenbuch Verlag) 1980, esp. vol. 1, Berlin et. al. (De Gruyter) 1980, p. 129-132.

9 Walter Benjamin: Berlin Childhood around 1900, trans. Howard Eiland, Cambridge/Mass. et. al. (The Belknap Press of Harvard University Press) 2006, p. 57. 
the Hesperides which granted immortality. Perhaps an unconscious desire leads Benjamin to this attempt to eternize his own infancy through memory and the reinterpretation of the past in terms of Greek myths.

Thus, even for Benjamin himself, one could define Berlin as the "Athens of the North." In this context of interpretation of the German as a revitalization of the Greek spirit, it is logical that the military victories of the Prussian armies were symbolically attributed to Athena or to Nike, the Greek Goddess of Victory who, in the popular mind, becomes an angel of the Christian tradition. There are two important moments in the appearance of the figures of the Goddess Nike or the Angel of Victory in the public sphere in the city of Berlin and of other German towns: in the first place, the celebration of the triumph over Napoleon and the French armies in 1815 gives rise to the monument of Viktoria Park (origin of the current neighborhood of Kreuzberg), the transformation of the Angel of Peace which guided the quadriga of the Brandenburg Gate into an Angel of Victory and the erection of other monuments with an Angel of Victory in the centre of the round plaza (baptized as the Plaza of Belle-Alliance, the name of the village in which Napoleon was vanquished) beside the Hallesches Tor, the gate of Berlin through which the bulk of the French army had entered to conquer the city. The second important moment happens after the three great wars of the 1860s and 1870s which consolidate Prussian power in Central Europe and the construction of a unified Germany under its direction: the victories over Denmark in 1864, over Austria in 1866, and over France in 1871. These three victories, and especially the great triumph over the French in the Battle of Sedan, were the motive for the erection of the monument of what is called the Siegessäule (»Victory Column«), above which there appears a giant figure of Nike or of the Angel of Victory; as we will see later, Walter Benjamin wrote about this figure in the book which collects his memories of his childhood in Berlin.

\section{French Connection}

Before continuing with Berlin, I wish to briefly address France because statues of the Goddess Nike (or better yet, the Goddess of Victory in her Roman guise) had previously appeared there, especially in Paris, at the beginnings of the $19^{\text {th }}$ Century to celebrate Napoleon's great military triumphs across Europe. During his years of exile in Paris, Walter Benjamin had time to experience the continuity between the use of the Roman Victory in the era of the Old Regime and the 
new use under Napoleon. Very close to his customary working spot in the old headquarters of the National Library, Benjamin could contemplate the Angels of Victory which adorned the façades of the palace of the Louvre or, if he walked in the other direction, he could encounter the Place des Victoires, in whose centre there stands an equestrian statue of a triumphant Luis XIV, crowned with laurel by Victory. I can only present here some examples of the importance of the Angel of Victory in French political culture:

1) At the beginnings of the $19^{\text {th }}$ Century, when Napoleon still won all his battles, a column with a statue of the Goddess of Victory was built in the Place du Chatelet. And also, between 1806 and 1810, to celebrate Napoleon's great triumph in the Battle of Austerlitz, the famous Column in the Place Vendôme was erected. This Column is covered with bronze plates taken from the cannons of the defeated Austrian and Russian armies. And above it was a large statue of Napoleon, dressed as a Roman, crowned with laurel, with his left hand upon his sheathed sword and carrying in his right a figure of Victory standing upon a ball of the world to symbolize his vast power. Benjamin knew both these plazas and their monuments during his numerous stays in the French capital.

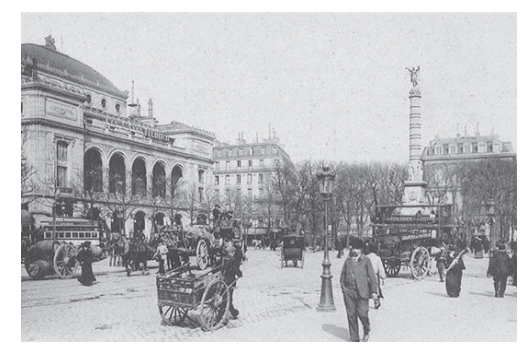

Ill. 6: Place du Chatelet in Paris with the Goddess of Victory.

2) Antonio Canova (1757-1822), the great Italian Neoclassical sculptor, symbolizes Napoleon as Mars, the God of War, who carries in his hand a Goddess of Victory. Napoleon didn't like seeing himself in this guise, naked and monumental in size, and rejected the sculpture. Currently there exist two versions of Napoleon made divine, one in Milan, in the courtyard of the Brera art gallery, and the other in the stairwell of Apsley House, the House of Wellington in London, who received the statue as a gift for the victory over Napoleon. 


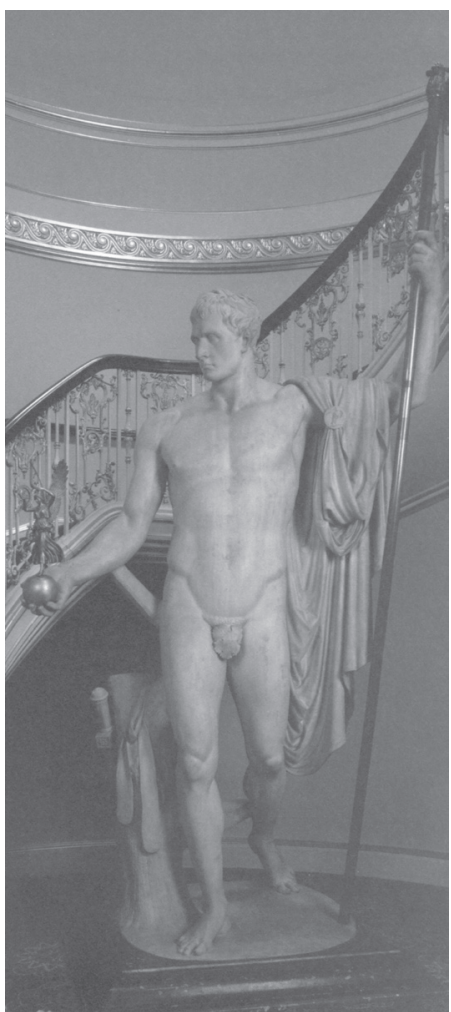

Ill. 7: Canova, Napoleon as Mars (God of War) with Victory in his right hand, Apsley House, London.
3) In the year 1873, two years after France's military defeat before Prussia, the French sculptor Antonin Mercié presented the "Gloria Victis" group, created in memory of a friend of his, fallen in the final days of the war. A winged Victory, posed in flight and lifting from the pedestal, moves forward carrying in her arms a dead naked youth, with a broken sword, symbol of the French youth massacred in the battlefields of the Franco-Prussian war of 1870-1871. This is a Goddess of Victory of the vanquished, an Angel of Victory of the victims of war. A copy of the sculpture was in the Royal Palace of Berlin and can be seen today in the Museum of German History. For a time, I thought of this work by Mercié as a representation of Benjamin's idea about the Angel of the Defeated. It is probable that Benjamin knew the "Gloria Victis" in one of the widespread French copies, although possibly not in the copy of the Royal Palace of Berlin since he had no entry there. In any case, Benjamin doesn't cite Mercié's work, and today I am inclined to think that this Angel of the Victory of the Defeated is overly tinged by French nationalism for it to have been considered a good image of the Angel of History. In Benjamin this is not a case of substitution of German Nationalism for French Nationalism, but rather of seeing history as an accumulation of catastrophes from the point of view of the vanquished, not of those who consent to fight again to transform defeat into a future military victory. Without a doubt, the angel carries the body of the war casualties and symbolizes the pain of loss or the search for consolation, but it is also a call to the hope of a future victory of the French armies and that is how it was popularly seen and acclaimed on an official level. At no moment does Mercié close the vicious circle of war and the dialectic of conquerors and vanquished, but rather he prepares the path of the national French conscience to look for a future military victory springing from their current defeat. 
4) Some time later, Victory also appears in Paris as an ornament of some commercial arcades, about which Walter Benjamin wrote during long and painful years in his unfinished masterpiece, The Arcades Project. In the Galerie Vivianne we can still see the celebration of the triumph of the Goddess of Merchandise and that of Economic Progress in the figures of some winged Victories, with palms and laurel wreaths in their hands. Benjamin mentions the Galerie Vivianne various times and, in one of them, he refers to the sculptures of the door which represents allegories of commerce and to the copy of an ancient Mercury on a pedestal or plinth in one of the interior courtyards, but he doesn't mention these victorious angels, despite the fact that he could not have failed to see them during his intense years of work in the old French National Library, located just in front of it, on the other side of the street. ${ }^{10}$

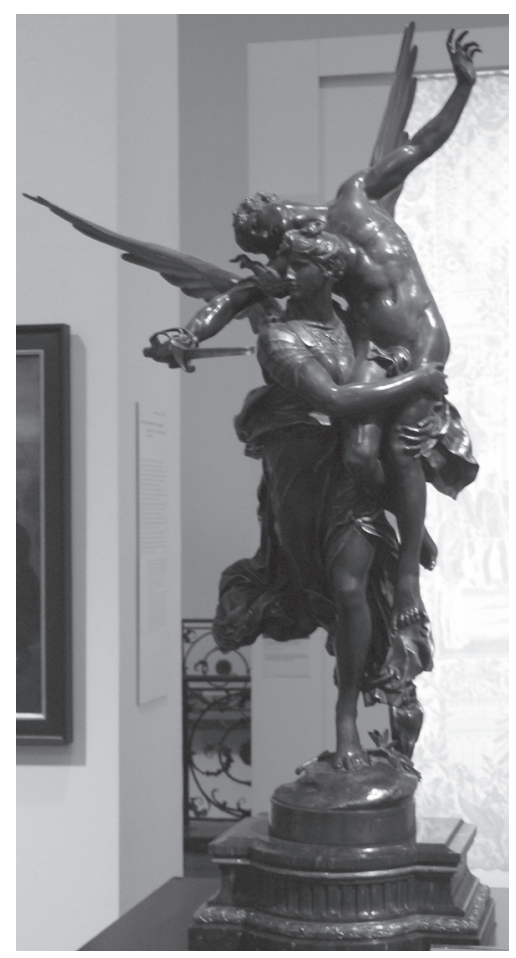

Ill. 8: Antonin Mercié, "Gloria Victis«, Deutsches Historisches Museum, Berlin.

\section{To be a »Flâneur« with Benjamin across Berlin in search of angels}

In the political iconography of Berlin, as I have already said, the $19^{\text {th }}$ Century represents the downfall of the Goddess Fortuna and her replacement by the glorious ascent of the Goddess Nike, followed by her transformation into the Angel of Victory. Thus, Berlin becomes a "city of angels" and one must understand Benjamin's reflections on his childhood and his figure of the Angel of History in this context. Germany's defeat in the First World War marks the passage of the Angel of Victory to a second plane, but it is worth noting as well that the reappearance of the angels in Win Wenders' films reconnects with this tradition.

10 Vgl. Walter Benjamin: The Arcades Project, trans. Howard Eiland/Kevin McLaughlin, Cambridge/Mass. et al. (The Belknap Press of Harvard University Press) 1999, p. 203. 
His films Wings of Desire (Der Himmel über Berlin, 1987) and Faraway, So Close! (In weiter Ferne, so nah!, 1993) represent a new vision of the subject of angels

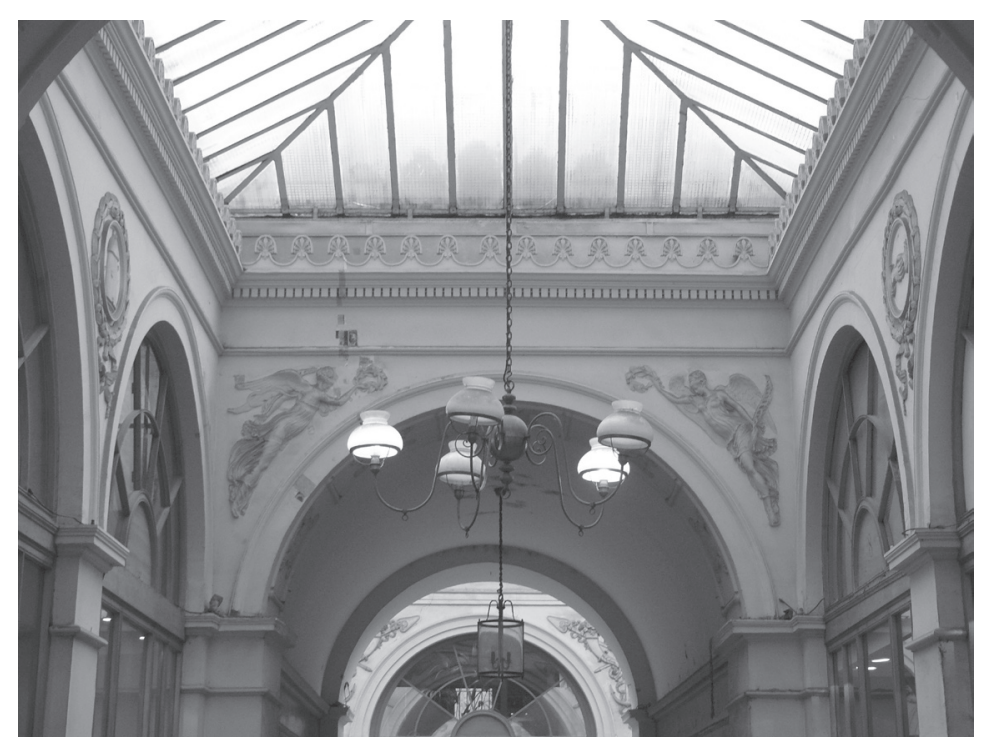

Ill. 9: Galerie Vivianne, Paris.

and it would be worth speaking of the angel above the angel, given that one of the favorite places that the angels Cassiel (Otto Sander) and Damiel (Bruno Ganz) use as a vantage point from which to contemplate the city and understand the joys and sorrows of its inhabitants is precisely from the Angel of Victory, the Siegessäule, converted into a symbol of Berlin.

For some months I wandered through Berlin, camera at the ready, in search of lost angels, trying to view the city through Benjamin's eyes. And my interest has not been so much the angels of the churches, but rather the Goddess Nike or the Angel of Victory in the city's public and political spaces. It's clear that many buildings were forever lost in the bombings of the Second World War, among those Benjamin's birthplace at number 4 of Magdeburgplatz or the family's next home at Kurfürstenstraße 154. The war did spare the family dwelling in Carmerstraße 3, beside the Savignyplatz and the school which Walter Benjamin attended for a few years as a child, and also the house at Nettelbeckstraße 24. Finally, the last of the houses of Benjamin's parents, in Delbrückstraße 23, was also destroyed. Always staying in the Bourgeois and well-to-do neighborhoods 
of West Berlin, the family progressively moved a little further from the centre each time, ending in Grunewald, a neighborhood outside the city limits at the time although now within them. Other settings of Benjamin's Berlin have also disappeared, making the task of searching for lost angels complicated, but despite everything, many are still visible today.

I am only going to show two examples of the profusion of angels in the decoration of the Bourgeois homes of the time of the Gründerzeit, that is to say, of the years that stretch from the Franco-Prussian War (1870-1871) until the beginning of the First World War in 1914 and which correspond with the great urbanistic development of Berlin and its accelerated industrialisation. The first example is from the door of a home in the Steinplatz:

Ill. 10: Angels on the door of Steinplatz Number 1 .

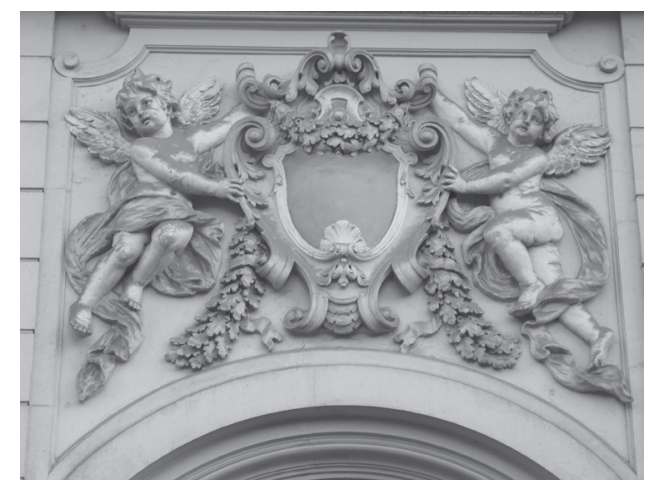

Although Benjamin does not mention this door just beside his family home at Carmerstraße 3, where he lived during his first school years, it could serve well as an example of the guardian angels of doors, which were his favorites. In his evocation of the Tiergarten, the park of his games and his earliest memories, Benjamin writes of his return thirty years later to the settings of his Berlin childhood and mentions the figures that guarded the lintels of the surrounding villas, just as they did in so many homes of the Berlin bourgeois at the beginnings of the $20^{\text {th }}$ Century:

Among the caryatides and atlantes, the putti and pomonas, which in those days looked on me, I stood closest to those dust-shrouded specimens of the race of threshold dwellers - those who guard the entrance to life, or to a house. For they are versed in waiting. Hence, it was all the same to them whether they waited for a stranger, for the return of the ancient gods, or for the child that, thirty years ago, slipped past them with his schoolboy's satchel. ${ }^{11}$

11 Benjamin: Berlin Childhood around 1900 (note 9), p. $56 \mathrm{f.}$ 
An official building is found in the same square (Steinplatz), the University of Arts, on whose façade - above a legend about the need to instruct the youth in the arts - we can see the following representation of an Angel of Victory with the symbols of the palm and the olive branch. Benjamin must have also seen this figure as a child:

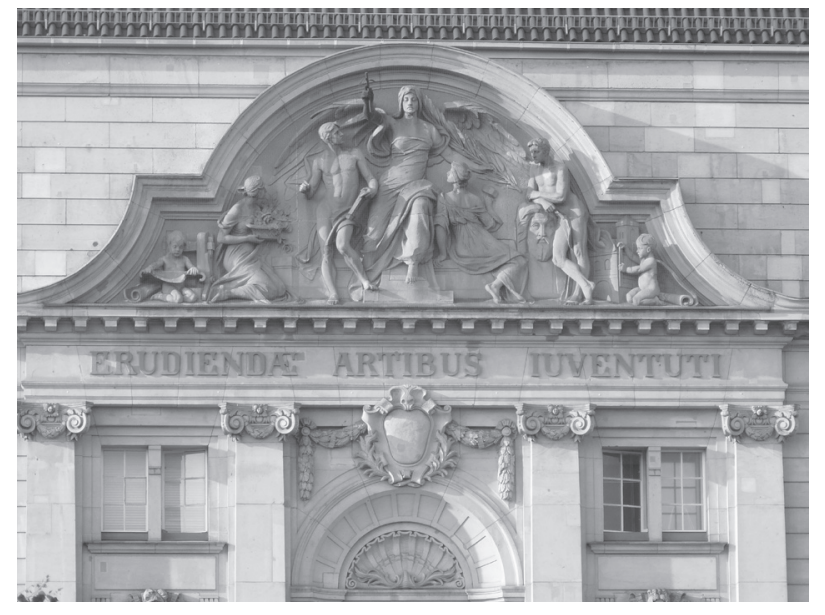

Ill. 11: The Angel, educator of youth.

On the other hand, there is a vast profusion of Victories along the axis which marked the political representation in Berlin from the $18^{\text {th }}$ Century until the middle of the $20^{\text {th }}$ Century: the famous Unter den Linden avenue. It was the stage for various military parades and the primary political ceremonies which served to theatralize power and to demonstrate basic values and the hierarchization of society before spectators. Especially on the first public buildings which make up what is called the forum fredericianum (the forum or public plaza of Frederick the Great), the figure of the Angel of Victory is repeated in an almost obsessive fashion, especially on the buildings or public sculptures built after the wars of liberation against Napoleon. Here I can only give two examples, one from the beginning and the other from the end of Unter den Linden.

The avenue begins in the Schlossbrücke, the bridge of the royal palace, also popularly called the "bridge of angels" because of the statues which adorn it. The bridge was designed by Karl Friedrich Schinkel and completed in 1824. The sculpture cycle above the bridge shows in eight sequences "the life of a warrior, from youth until death" and they were carved according to Schinkel's drawings, although they were not finished and placed in their current positions until the years between 1853 and 1858, a significant time after his death. Here I can only reproduce one of the sculptural pictures from the bridge, which shows us the 
Angel of Victory crowning with laurel a military man who returns home after having been triumphant in the war.

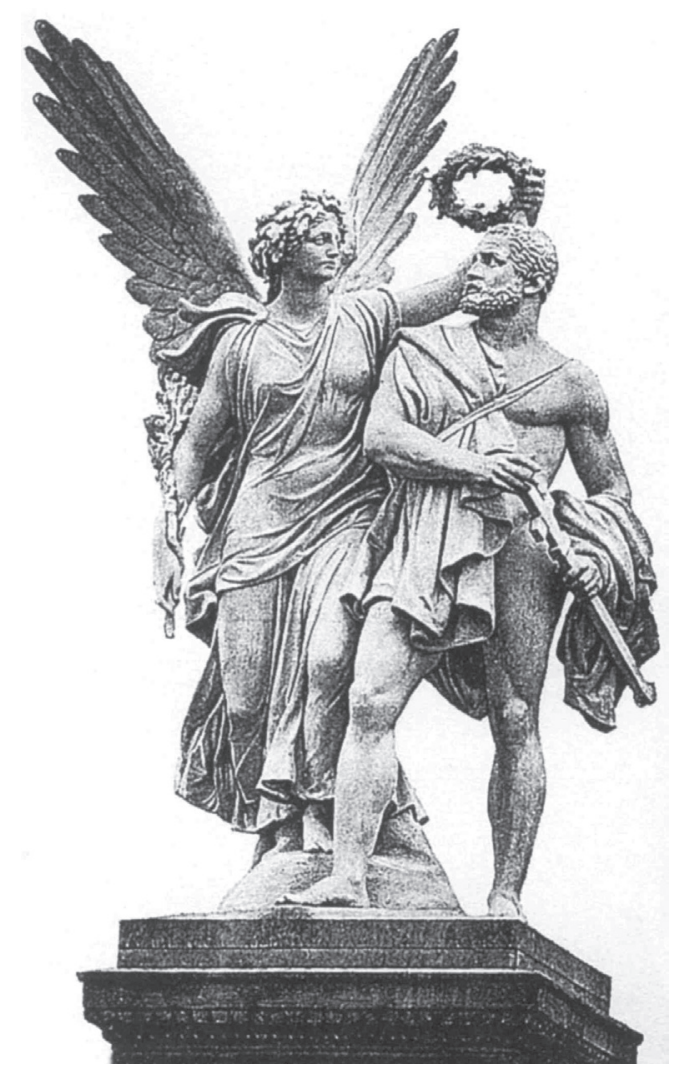

Ill. 12: The Angel of Victory crowns a victorious warrior returning home.

The end of Unter den Linden is marked by the Plaza of Paris and the Brandenburg Gate, with its quadriga led by an angel, another of the great symbols of Berlin. The change of symbols with this angel is significant. Originally, the sculpture by Johann Gottfried Schadow (1764-1850) represented the Angel of Peace leading the carriage, for it was a monument to the Peace of Basel of 1795. Napoleon I's entry through the Brandenburg Gate transformed it into a victory gate and his decision to bring the quadriga to Paris as booty of war to place it as a coronation of the Madelaine, the temple dedicated to his glory and the victories of his armies across all Europe, provoked the indignation of the Berliners and a metamorphosis 
of the symbols. In effect, after Napoleon's defeat the carriage returned to Berlin in triumph and was again placed above the Brandenburg gate, but with a small change: the addition of the iron cross above which a royal Prussian eagle rests, transforming the symbolism of the Angel of Peace into the Angel of Victory. ${ }^{12}$

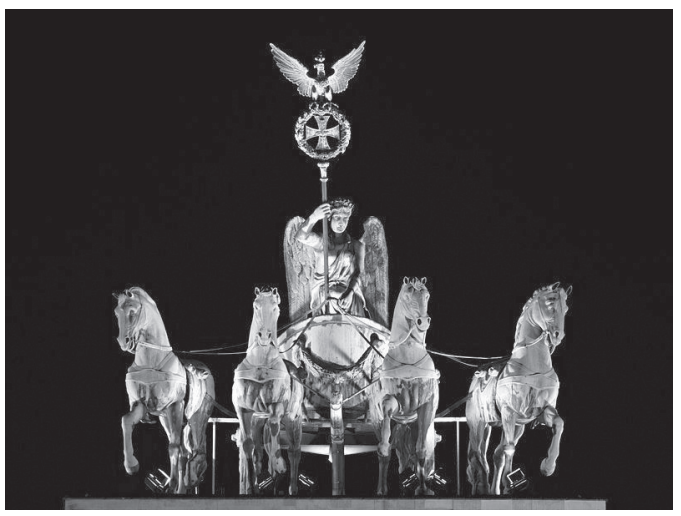

Ill. 13: The Angel of Peace/Victory above the carriage of the Brandenburg Gate.

In this fashion, the cycle of the Unter den Linden axis closes in the same way as it began, with a vision of the Angel of Victory.

\section{Two texts by Benjamin and their two corresponding images}

The city as a text, a palimpsest and a labyrinth, are the primary Benjaminesque metaphors which express the relationship between writing and the metropolis. This is a case of reading the city according to the metaphor of the book applied to nature, but also to society and politics. In the preparatory materials for The Arcades Project, Benjamin writes the following: "The expression the book of nature indicates that one can read the real like a text. And that is how the reality of the nineteenth century will be treated here. We open the book of what happened. ${ }^{13}$ And nonetheless, as Susan Buck-Morss indicated, to read reality as if it were a text is to recognize the difference between both, a difference which Benjamin himself reflects in another quote, a few pages later of the same Arcades Project, in which he affirms the difference between a commentary about reality needing a totally different method from a commentary about a text. ${ }^{14}$

12 Vgl. Reinhart Koselleck: Zur politischen Ikonologie des gewaltsamen Todes. Ein deutsch-französischer Vergleich, Basel (Schwabe \& Co.) 1998, p. 20-22.

13 Benjamin: The Arcades Project (note 10), p. 464.

14 Ibid., p. 460. 
The city is a complex text and also as a labyrinth in which to lose oneself. Benjamin discovers the mythic aspect of the great city as labyrinth in Baudelaire's work about Paris, but he also reconognises it as an experience from his own childhood in the German capital: a labyrinth of streets through which the flâneur wanders, but also the labyrinth of memory which tries to remember the entrails of the past. In the book which recounts his childhood experiences in the great city of Berlin, Benjamin writes:

Not to find one's way around a city does not mean much. But to lose one's way in a city, as one loses one's way in a forest, requires some schooling. Street names must speak to the urban wanderer like the snapping of dry twigs, and little streets in the heart of the city must reflect the times of day, for him, as clearly as a mountain valley. ${ }^{15}$

Following, he evokes the first labyrinths of his memory, the labyrinths of the blotting paper of his childhood notebooks, and before them, the path of the labyrinth which led from the house of his birth to his favorite park, the Tiergarten, crossing the canal by the gentle arch of the Bendler Bridge. And he did not lack an Ariadna who, with her thread, made the labyrinth of the park traversable, helping him to cross it to his favorite statues of Frederick William and Queen Luisa, or to discover new corners in which to lose himself. Benjamin remembers his particular Ariadna, Luisa von Landau, who lived on one of the borders of the park, on the other side of the canal, in the Lützowufer, and with whom he first knew what only later he could raise to the level of words: Love.

In the past decades, various analysts have insisted on the importance of the city in Walter Benjamin's work. In critical continuity with Susan Buck-Morss and David Frisby's monographs, Graeme Gilloch writes the following in his book about Walter Benjamin and the city:

In his writings Benjamin is preoccupied with the visual and imagistic. The early cityscapes are Denkbilder, "thought-images", which seek to portray the city, be it Naples, Moscow, or Marseilles, through a kind of journalistic reportage. The Berlin texts are primarily composed of constellations of remembered images (autobiography and personal narrative are attempts to recapture the "at first sight" of the city), and in the Passagenarbeit Benjamin stresses the visual character of history and the methodological imperative of the dialectical image. The cityscapes are attempts, therefore, to translate the seen into the written, the picture into the

15 Benjamin: Berlin Childhood around 1900 (note 9), p. 54 f. The city as a labyrinth is also a frequent metaphor in Zentralpark (GS I, 655-690). 
word, to articulate what Buck-Morss refers to in the title of her 1989 study "the dialectic of seeing. $\aleph^{16}$

Without a doubt, the city is one of Benjamin's central themes. Memories of his childhood in Berlin, Berlin Chronicles, radio speeches about his native city, the culture of flanerie in Berlin and Paris. The city is a text which speaks to us and which we should listen to, interpret and read. The experiences of the big city are also cinematographic scenes which we must assemble, experiences that are unconnected between themselves and which resemble the pieces of a puzzle. In a letter to his friend Gershom Scholem, Benjamin himself defines his book Berlin Childhood around 1900 not as a chronicle but rather as fragments and "isolated expeditions into the depths of memory. ${ }^{17}$ The city is a labyrinth in which to lose oneself and the text is also a labyrinth which we must interpret and navigate through. City and text are presented as coextensive: the city is a complex text and the text winds up having characteristics similar to the great metropolis, difficult to understand or interpret and easy to lose oneself in its labyrinths. Benjamin's texts about Berlin don't only offer a vision of the city but are also the fruit of metropolitan experiences and carry them within. Again in Gilloch's words:

The dominance of the visual, the predilection for the fragmented and the concern with the immediate and with "shock" are both definitive characteristics of modern urban life and central formal properties of Benjamin's texts. As a modernist, Benjamin regards the city as a space of intoxication, of excitement and distraction. As a historical materialist, he rejects it as the site of bourgeois domination. Fluctuating between these positions, his texts both embody and resist those tendencies he considered central to, and characteristic of, modern capitalist society. In his loving and loathing of the urban complex, Benjamin may be seen as deeply enmeshed in those paradoxes that constitute the »heroism of modern life.$^{18}$

Into this context of reflections and memories about the city of Berlin one must insert Benjamin's text about the Goddess of Victory above the Siegessäule

16 Graeme Gilloch: Myth and Metropolis. Walter Benjamin and the City, Cambridge (Polity Press) 1996, p. 18. See also the book by Susan Buck-Morss: Dialectics of Seeing. Walter Benjamin and the Arcades Project, Cambridge/Mass. et. al. (MIT Press) 1989, as well as the monographs David Frisby: Fragments of Modernity. Theories of Modernity in the Work of Simmel, Kracauer and Benjamin, Cambridge (Polity Press) 1985, and id.: Cityscapes of Modernity. Critical Explorations, Cambridge (Polity Press) 2001.

17 Gershom Scholem: Walter Benjamin. Die Geschichte einer Freundschaft, Frankfurt a.M. (Suhrkamp) 1977, p. 238.

18 Gilloch: Myth and Metropolis (note 16), p. $19 \mathrm{f}$. 
(Victory Column), the monument erected in the old Königplatz, in front of the Parliament (Reichstag), to commemorate the great victories of the Prussian armies in the wars against the Danish (1864), the Austrians (1866), and the French (1870-1871). After the burning of the Reichstag, the Nazi's moved the Victory Column to its current placement in the Grosser Stern, a large plaza in which five wide avenues converge in the centre of the Tiergarten park. But Benjamin knew it when it was in its initial placement, at the end of the Avenue of Victory, a street occupied at that time with statues of the heroes of German nationalism and which lead to the Königsplatz and the Parliament. It is significant that Walter Benjamin chose as the motto of his book Berlin Childhood around 1900 some lines which are difficult to interpret but which make us see the central role of this monument in his memories: „Oh, golden Victory Column / with winter sugar / of the days of childhood. ${ }^{19}$ In this way, the Victory monument seems to also be the centre of the book and not just one of its sections. The fragment dedicated to the Victory Column begins with the confirmation that the monument is found in the middle of the wide plaza, like the date printed in red in the almanac, and ends with an ironic reference to an eternal Sunday or to an eternal »Day of Sedan", that is to say, a constant commemoration of German Nationalism and of the victory against the French in the Battle of Sedan which marked the turning point of the Franco-Prussian War. Benjamin remembers the celebrations of his childhood marked by the military parades and declares that the statue of the Goddess of Victory should have been destroyed with the last celebration of the Day of Sedan. In this context of triumph, the end of the history which culminated in the glorification of Germany seemed to have arrived: "With the defeat of the French, world history seemed to be safely interred in its glorious grave, and this column was the funerary stele. ${ }^{20}$

Later, Benjamin describes the impressions his visit evoked for him, as a student in the third level in school, and his difficulties in understanding the explanations. Ironically, he made the following comment: "Someone had explained to me where the decorations for the Victory Column came from. But I was still rather confused about the cannon barrels included among them. Had the French gone to war with golden cannons, or had we first taken the gold from them and then used it to cast cannons? «1

19 According to Gershom Scholem, the verses come from a short surrealist poem written by Benjamin while under the effects of hashish. Compare as well to the article by Gershom Scholem: "Epílogo a Crónica berlinesa de Benjamin" (Epilogue to Benjamin’s Berlin Chronicles (1970), collected in his book Walter Benjamin y su ángel (Walter Benjamin and his Angel), Mexico (FCE) 1998, p. 183-188. The complete poem can be seen in: GS VI, 618.

20 Benjamin: Berlin Childhood around 1900 (note 9), p. 46.

21 Ibid., p. $46 \mathrm{f}$. 


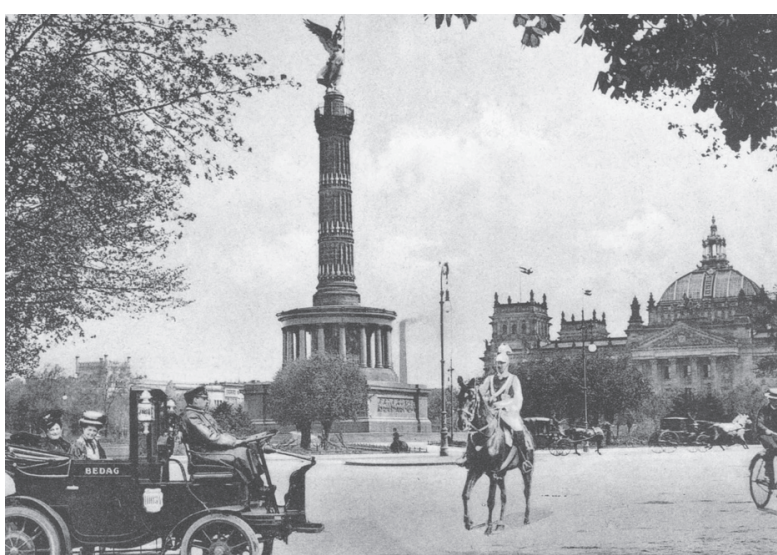

Ill. 14: "Siegessäule« (Victory Column) in front of Parliament(Reichstag), as it was seen by Walter Benjamin around 1900 .

Benjamin makes a reading of the Victory Column from the perspective that any cultural document is at the same time a document of barbarism and counterposes the "circle of Grace « above and around the splendid figure of Victory with what he calls the "Inferno" of the inferior gallery, in which the triumph of the Germans and the constitution of the Second Reich in Versailles is symbolized: the heroes depicted here remind him of the scenes which he had examined in his book about Doré's etchings about Dante's Inferno.

I want to place this text by Benjamin into context with the well-known ninth thesis from his $O n$ the Concept of History. Both texts are worth being read simultaneously, so that we can also see at the same time the two images to which they refer. In both cases this concerns angels, even if one of them symbolizes different and even opposing elements. Below I transcribe the complete text of the ninth Thesis which begins with a quotation of a poem by Gershom Scholem dedicated to a Paul Klee painting ${ }^{22}$ titled Angelus Novus and continues with the text by Benjamin in which he makes his personal interpretation of the same painting, converting the Angelus Novus into the Angel of History:

My wings are ready for flight,

I would like to turn back.

If I stayed everliving time,

I'd still have little luck.

Gershom Scholem, "Greetings from the Angelus"

22 Compare to the article written by Gershom Scholem in $1972 »$ Walter Benjamin und sein Engel«, collected in the book of the same title: Walter Benjamin und sein Engel, Frankfurt a. M. (Suhrkamp) 1983, p. 35-72. 
There is a picture by Klee called Angelus Novus. It shows an angel who seems about to move away from something he stares at. His eyes are wide, his mouth is open, his wings are spread. This is how the angel of history must look. His face is turned toward the past. Where a chain of events appears before us, he sees one single catastrophe, which keeps piling wreckage upon wreckage and hurls it at his feet. The angel would like to stay, awaken the dead, and make whole what has been smashed. But a storm is blowing from Paradise and has got caught in his wings; it is so strong that the angel can no longer close them. This storm drives him irresistibly into the future, to which his back is turned, while the pile of debris before him grows towards the sky. What we call progress is this storm. ${ }^{23}$

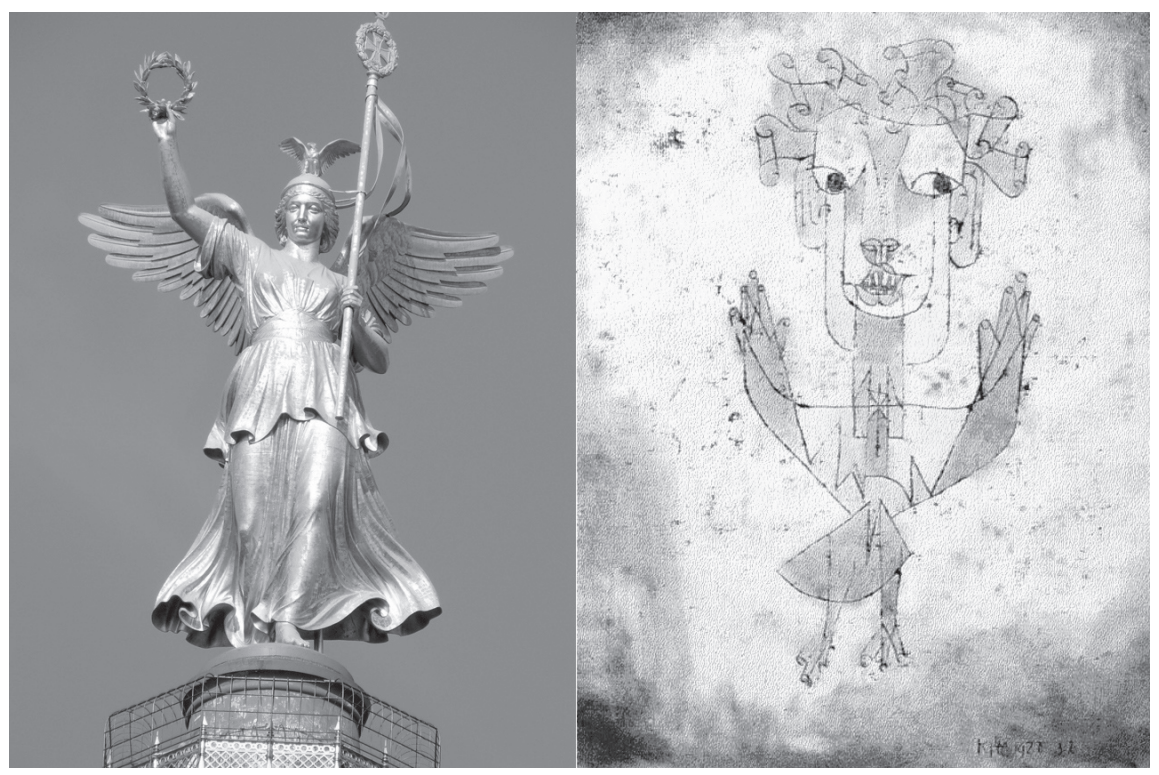

Ill. 15: The Angel of Victory and Angelus Novus.

23 Walter Benjamin: „On the Concept of History«, in: Selected Writings, vol. 4.: 1938-1940, ed. by Howard Eiland/Michael W. Jennings, trans. Edmund Jephcott et al., Cambridge/Mass. et al. (The Belknap Press of Harvard University Press) 2003, p. 392. I do not have space here to comment more extensively on Benjamin's 9th thesis. Among the countless analyzes of this thesis I wish to highlight two, one in German and one in Spanish: Sigrid Weigel: Entstellte Ähnlichkeit. Walter Benjamins theoretische Schreibweise, Frankfurt a. M. (Fischer) 1997, esp. ch. 3: "Dialektische Bilder und Messianismus - Eine Relektüre des Engels der Geschichte", p. 52-79 and Reyes Mate: Medianoche en la historia. Comentarios a las tesis de Walter Benjamin "Sobre el concepto de historia" (Midnight in History: Commentaries on Walter Benjamin's Thesis "On the Concept of History“), Madrid (Trotta) 2006, esp. ch. 9, „El ángel de la historia o porqué lo que para nosotros es progreso es para el ángel catástrofe« (The Angel of History or Why What for Us is Progress is Catastrophe for the Angel). 
Paul Klee's Angelus Novus is, in Benjamin's interpretation, the Angel of History, a perfect and true counterimage to the Goddess or Angel of Victory. Her characteristics can be compared as the heads and tails of a coin or like the positive and negative image of the same photograph. In fact, we could say that in Benjamin there exists not only one Angel of History but two: that represented in the watercolor by the Swiss expressionist painter, Paul Klee, and the angel of the Victory Column which dominates his memory of the bygone days of his childhood in Berlin. In the following two-column table I summarize some of the primary characteristics of both angels:

\begin{tabular}{|c|c|}
\hline Angel Of Victory (Siegessäule) & Angel Of History (Angelus Novus) \\
\hline Point of view of the winners. & $\begin{array}{l}\text { Point of view of the defeated, of the vic- } \\
\text { tims of history. }\end{array}$ \\
\hline Looks confidently to the future. & $\begin{array}{l}\text { Looks to the past, face turned to yester- } \\
\text { day, turning its back on the future: "the } \\
\text { hurricane pushes it relentlessly toward } \\
\text { the future, which it turns its back to, } \\
\text { while the accumulation of ruins grows } \\
\text { to the heavens. "Retrospective gaze of } \\
\text { history. }\end{array}$ \\
\hline History as constant progress. & $\begin{array}{l}\text { History only as catastrophe which accu- } \\
\text { mulates ceaselessly ruin upon ruin. }\end{array}$ \\
\hline Deification of progress. & $\begin{array}{l}\text { Vision of history as memory of the past, } \\
\text { memory of the defeated. }\end{array}$ \\
\hline Futurist myth of historic progress. & $\begin{array}{l}\text { History as the constant destruction of } \\
\text { Nature and of human relationships }\end{array}$ \\
\hline Victory moves forward. & $\begin{array}{l}\text { The Angel of History is carried back- } \\
\text { wards by the hurricane. (The Romantic } \\
\text { idea of the historian as prophet directed } \\
\text { toward the past, Friedrich Schlegel) }\end{array}$ \\
\hline Monumental scale, superhuman. & Small, of human scale. \\
\hline $\begin{array}{l}\text { Carries the symbols of victory in its } \\
\text { hands: the laurel wreath and the lance } \\
\text { with the iron cross. Victory is the fruit } \\
\text { of war. }\end{array}$ & Open hands, empty. \\
\hline
\end{tabular}




\begin{tabular}{|c|c|}
\hline Angel Of Victory (Siegessäule) & Angel Of History (Angelus Novus) \\
\hline $\begin{array}{l}\text { Represents German nationalism, the } \\
\text { national pride, the construction of the } \\
\text { German national identity in the Second } \\
\text { Reich. }\end{array}$ & $\begin{array}{l}\text { Anti-nationalism, represents a cosmo- } \\
\text { politan point of view. }\end{array}$ \\
\hline The winners write history. & $\begin{array}{l}\text { No one writes history from the point of } \\
\text { view of the conquered defeated. }\end{array}$ \\
\hline Power. & Impotence. \\
\hline $\begin{array}{l}\text { The Siegessäule is initially a Goddess } \\
\text { Nike in its Greek version or a Goddess } \\
\text { of Victory in its Roman name. Popularly } \\
\text { she is known as »Goldene Else« or also } \\
\text { as »Siegesengel« (Angel of Victory) }\end{array}$ & $\begin{array}{l}\text { We don't know exactly Paul Klee’s origi- } \\
\text { nal intention in creating the watercolor } \\
\text { titled »Angelus Novus.« }\end{array}$ \\
\hline $\begin{array}{l}\text { Victory has her feet firmly planted upon } \\
\text { the sphere of the world, which she hopes } \\
\text { to dominate. }\end{array}$ & Feet in the air, without any purchase. \\
\hline Victory is a winged goddess. & $\begin{array}{l}\text { Paul Klee's Angelus Novus lacks wings } \\
\text { (despite Benjamin's speaking of the un- } \\
\text { folded wings and the blowing winds } \\
\text { which eddy through them and prevent } \\
\text { her from folding them) }\end{array}$ \\
\hline $\begin{array}{l}\text { Benjamin is educated in this idea of his- } \\
\text { tory as the victory of the Germans, espe- } \\
\text { cially over the French, but also over the } \\
\text { Austrians and the Danish. }\end{array}$ & $\begin{array}{l}\text { Benjamin creates his own idea of history } \\
\text { as the memory of the conquered. }\end{array}$ \\
\hline $\begin{array}{l}\text { According to Benjamin, the Victory Co- } \\
\text { lumn should have been destroyed with } \\
\text { the last celebration of the Day of Sedan. }\end{array}$ & $\begin{array}{l}\text { The Angel of History substituted the } \\
\text { Angel (or Goddess) of Victory. }\end{array}$ \\
\hline
\end{tabular}

Benjamin's shift from a conception of history as progress, as the evolutionary development of the German nation and its victories over other nations, to an idea of history as the accumulation of catastrophes is worth highlighting. The exchange of one image for another, the nationalist winged Angel of Victory is substituted by Paul Klee's Angelus Novus, by that Angel of the Talmudic tradition, created by God in uncountable numbers at every moment, to sing his praises for a moment and then disappear.

None of the numerous commentators of Benjamin have realized the complementaryness of the two images of the Angel of History. Perhaps because, while 
Benjamin is an eminently visual thinker, the order of the writing continues to have precedence over the iconic, over the order of the images. Not even Susan Buck-Morss, in her monograph on the dialectic of Benjamin's gaze, in which image plays the important role which is its due, has come to see the contrast between Berlin's Victory Column and Benjamin's Angel of History. While in one of the passages of her book she has been close to relating the images of the two angels, in reality she winds up referring to a project for a Statue of Victory, proposed by Bigot in 1931 for the Rond Point de la Defense in Paris, which would celebrate French military triumphs, in particular those victories over Germany in the First World War. Buck-Morss counterposes the gigantic nature of said project with the figure of Paul Klee's Angelus Novus, which Benjamin uses for his own theoretical interests.

I would like to end bringing up a text from Central Park in which Benjamin compares the idea of history as catastrophe with a kaleidoscope in the hands of a child who, with each twist, destroys one order to create a new configuration of images.

The course of history, seen in terms of the concept of catastrophe, can actually claim no more attention from thinkers than a child's kaleidoscope, which with every turn of the hand dissolves the established order into a new array. There is profound truth in this image. The concepts of the ruling class have always been the mirrors that enabled an image of "order" to prevail. - The kaleidoscope must be smashed. ${ }^{24}$

The Siegessäule is a kind of kaleidoscope of the Bourgeois conception of history as indefinite progress in the $19^{\text {th }}$ Century and part of the $20^{\text {th }}$ until the Second World War. According to Benjamin, the Siegessäule, just like the kaleidoscope, should also have been destroyed when the final Day of Sedan was celebrated, the victory over the French in the Franco-Prussian War of 1870-1871. We must change our concepts of history. And also our images.

24 Benjamin: Central Park, in: SW IV, 164 (note 23). 
Abb. 2

Ursprung des deutschen Trauerspiels (1924), Walter Benjamin Archiv der Jewish National \& University Library in Jerusalem; abgebildet: S. 3 (Ausschnitt). Vgl. GS I, 924-950 [Signatur: Arc.4* 1598/109]. Maßstab: 1:1.

Abb. 3

Ursprung des deutschen Trauerspiels (1924), Walter Benjamin Archiv der Jewish National \& University Library in Jerusalem; abgebildet: S. 2. Vgl. GS I, 924-950 [Signatur: Arc.4* 1598/109]. Maßstab: 1:1,4.

Abb. 4

Ursprung des deutschen Trauerspiels (1924), Walter Benjamin Archiv der Jewish National \& University Library in Jerusalem; abgebildet: S. 3. Vgl. GS I, 924-950 [Signatur: Arc.4* 1598/109]. Maßstab: 1:1,4.

Abb. 5

Ursprung des deutschen Trauerspiels (1924), Walter Benjamin Archiv der Jewish National \& University Library in Jerusalem; abgebildet: S. 4. Vgl. GS I, 924-950 [Signatur: Arc.4* 1598/109]. Maßstab: 1:1,4.

Abb. 6

Ursprung des deutschen Trauerspiels (1924), Walter Benjamin Archiv der Jewish National \& University Library in Jerusalem; abgebildet: S. 5. Vgl. GS I, 924-950 [Signatur: Arc.4* 1598/109]. Maßstab: 1:1,4.

Abb. 7

Ursprung des deutschen Trauerspiels (1924), Walter Benjamin Archiv der Jewish National \& University Library in Jerusalem; abgebildet: S. 3 (Ausschnitt). Vgl. GS I, 924-950 [Signatur: Arc.4* 1598/109]. Maßstab: 1:1,4.

Abb. 8

Ursprung des deutschen Trauerspiels (1924), Walter Benjamin Archiv der Jewish National \& University Library in Jerusalem; abgebildet: Sp. 19 (Ausschnitt). Vgl. GS I, 924-950 [Signatur: Arc.4* 1598/109]. Maßstab: 1:1.

\section{José M. GonZÁlez García}

\section{Walter Benjamin: The Angel of Victory and the Angel of History}

Abb. 1-3, 5, 7-11, 13

Aufnahmen: José M. González García.

Abb. 4

Rudolf G. Scharmann: Schloss Charlottenburg, Stiftung Preußische Schlösser und Gärten, München (Prestel) 2005, S. 19.

Abb. 6

Fotograf unbekannt, ca. 1900. 
Abb. 12

Fotograf unbekannt, 1888, in: Paul Wietzorek: Das historische Berlin. Bilder erzählen, Petersberg (Michael Imhof) 2006, S. 114.

Abb. 14

Fotograf unbekannt, ca. 1890.

Abb. 15

Links: Aufnahme von José M. González García; rechts: Paul Klee: „Angelus Novus« (The Israel Museum, Jerusalem).

\section{Reinhard MeHRING}

"Geist ist das Vermögen, Diktatur auszuüben«.

Carl Schmitts Marginalien zu Walter Benjamin

Abb. 1:

Nachlass Carl Schmitt (Landesarchiv NRW. Abteilung Rheinland. Standort Düsseldorf), Bild-Nr. RW_265_01228_001.

Abb. 2:

Nachlass Carl Schmitt (Landesarchiv NRW. Abteilung Rheinland. Standort Düsseldorf), Bild-Nr. RW_265_29012_001.

Abb. 3:

Nachlass Carl Schmitt (Landesarchiv NRW. Abteilung Rheinland. Standort Düsseldorf), Bild-Nr. RW_265_29012_002.

Abb. 4:

Nachlass Carl Schmitt (Landesarchiv NRW. Abteilung Rheinland. Standort Düsseldorf), Bild-Nr. RW_265_29012_003.

\section{HeinRich KaUlen}

„Der ironische Engel«. Walter Benjamins Lektüre von Giacomo

Leopardi im Spannungsverhältnis der Aphoristik nach 1800 und der zeitgenössischen Anthropologie

Abb. 1

Aus: Giacomo Leopardi: Gedanken. Deutsch von Richard Peters. HamburgBergedorf 1928, S. 10.

Abb. 2

Photo: Ad Meskens, Wikimedia Commons. 